\title{
Effects of Herbal Supplement Tribulus Terrestris: A Mini Review
}

ISSN: 2577-1914

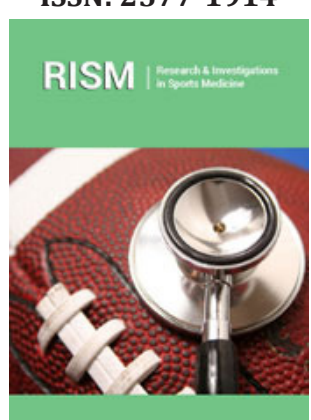

*Corresponding author: Bruno Nascimento-Carvalho,Human Movement Lab, Universidade São Judas Tadeu (USJT), Brazil

Submission: 海 August 01, 2019

Published: 跙 September 19, 2019

Volume 5 - Issue 3

How to cite this article: Bruno $\mathrm{N} C$, Miguel A C M, Oscar Albuquerque d M, Adriano d S, Erico Chagas C, et al. Effects of Herbal Supplement Tribulus Terrestris: A Mini Review. Res Inves Sports Med. 5(3). RISM.000611.2019.

DOI: 10.31031/RISM.2019.05.000611

Copyright@ Bruno Nascimento-Carvalho, This article is distributed under the terms of the Creative Commons Attribution 4.0 International License, which permits unrestricted use and redistribution provided that the original author and source are credited.

\author{
Bruno Nascimento Carvalho, ${ }^{1,2 *}$, Miguel Angel Condori Mayta1, Oscar Albu- \\ querque de Moraes $^{2}$, Adriano dos Santos ${ }^{1}$, Erico Chagas Caperuto ${ }^{1}$, Katia \\ Bilhar Scapini ${ }^{1}$, Bruno Nascimento Lopes ${ }^{1}$, André Rinaldi Fukushima ${ }^{3,4}$ and \\ Iris Callado Sanches ${ }^{1}$ \\ ${ }^{1}$ Human Movement Lab, Universidade São Judas Tadeu (USJT), Brazil \\ ${ }^{2}$ Hypertension Unit, Heart Institute (InCor), University of Sao Paulo Medical School, Brazil \\ ${ }^{3}$ Department of Pathology, School of Veterinary Medicine and Animal Science, University of \\ São Paulo, Brazil \\ ${ }^{4}$ Department of research and extension, Igesp Health Sciences College, Brazil
}

\begin{abstract}
Terrestrial Tribulus is an herbaceous plant originally from India. It has been widely used as a natural sexual stimulant by the traditional medicine of China, India and Greece. Tribulus is now widely used mainly by athletes based on the belief that it can increase testosterone concentrations. However, there is no consensus on the real effects of this supplementation, so the aim of this research was to characterize the effects of Tribulus in experimental models. This mini review was performed in the PubMed database on 04/13/2019 with the terms: "Terrestrial Tribulus", "mice" and their related terms. Only studies in Portuguese, Spanish, English, Italian and French were included. In addition, all in vitro studies, studies that did not demonstrate in the methodology the use of Terrestrial Tribulus supplementation and studies that were not obtained in full were excluded. With this search strategy, 33 articles were identified, from which 18 studies were excluded based on the eligibility criteria. The results showed a protective effect on the male reproductive system, increased antioxidant agents and anti-inflammatory effect induced by supplementation of Terrestrial Tribulus.
\end{abstract}

Keywords: Tribulus Terrestris, Male reproductive system, Oxidative stress, Inflammation

\section{Introduction}

The evidence of the positive effects of Terrestrial Tribulus supplementation in sexual performance, in decreasing oxidative stress and produce anti-inflammatory effects [1-3]. However. There is no consensus on the real benefits of supplementation, considering all its compounds. The aim of this mini review performed at PubMed was provide evidence in a controlled environment of the real effects, the search was performed in PubMed of on the day 13/04/2019 with Tribulus, Mice and their related terms. With this search strategy 33 articles were identified, from which 18 studies were excluded based on the eligibility criteria (were excluded studies in vitro and that not used Tribulus).

\section{Discussion}

Regarding the methodology proposed in the 15 studies included in this review (Table 1). We identified a consensus on the dose of supplement application (100 or $200 \mathrm{mg} / \mathrm{kg}$ ), of these studies $73.33 \%$ performed gavage on animals and almost all studies $86.66 \%$ applied the supplement daily, there was no standard for the period of supplement application (Table 2). However, this mini review provided performed interesting results. Only 33,3\% of studies identified some positive effect induced by Terrestrial Tribulus supplementation related to male sexual dysfunctions, in all these studies Tribulus supplementation aided the recovery of the reproductive system of the animals or produced a protective effect [4-8]

Although some studies relate benefits in the male reproductive system to increased testosterone production, a recent clinical trial has shown that this supplementation only increases the availability of testosterone associated with other substances, and its positive 
effects on the male reproductive system would be associated with higher availability of nitric oxide [9]. An antioxidant effect was observed in three studies using different models (model of Parkinson disease, male sexual dysfunction model and chemo preventive model) $[5,10,11]$. The increased nitric oxide production and reduced oxidative stress may be and the determining mechanisms to reduce the inflammatory profile, it is worth mentioning that in models that induced some kind of inflammation (atopic dermatitis, acute pancreatitis and rheumatism) Tribulus supplementation was effective in reducing these deleterious effects [12-14]. Considering the specificity of sports context, the main benefits of Tribulus (decreased stress oxidative and inflammatory) apply in exercise training of high intensity, where athletes present an imbalance in oxidative stress, increased of agents pro-inflammatory and energy imbalance $[15,16]$. These contexts, the supplementation with antioxidant and anti-inflammatory agents it's a strategy is effective in promotion protection for athletes, because it helps the return to homeostasis and consequently the maintenance of the performance $[15,16]$.

Table 1: Characteristic and effects of the included studies.

\begin{tabular}{|c|c|c|c|c|c|}
\hline Author & Year & Species & Model & Gender & Effects of Tribulus terrestris Extract \\
\hline $\begin{array}{c}\text { Alzahrani S } \\
{[10]}\end{array}$ & 2018 & Swiss albino & Parkinson & $\begin{array}{c}\text { High dosage of Tribulus induced benefits for the locomotor system of } \\
\text { animals with Parkinson and decreasing oxidative stress }\end{array}$ \\
\hline $\begin{array}{c}\text { Kumari M [4] } \\
\text { Pavin N [8] }\end{array}$ & 2018 & Swiss & Sexual dysfunction & male & High dosage of Tribulus induced decreasing of effects related to \\
infertility
\end{tabular}

NR: Not Reported by the Author

Table 2: Information's of dosage, via of application, frequency and period of application supplement.

\begin{tabular}{|c|c|c|c|c|c|}
\hline Author & Year & Dosage & Via & Application Frequency & Application Period \\
\hline Alzahrani S [10] & 2018 & 5 or $10 \mathrm{mg} / \mathrm{kg}$ & Gavage & all days & 17 days \\
\hline Kumari M [4] & 2018 & 100 or $200 \mathrm{mg} / \mathrm{kg}$ & Gavage & all days & 28 days \\
\hline Pavin NF [8] & 2018 & $11 \mathrm{mg} / \mathrm{kg}$ & Gavage & all days & 14 days \\
\hline Abu-Gharbieh E & 2018 & 100 or $200 \mathrm{mg} / \mathrm{kg}$ & Gavage & all days & 5 days \\
\hline Kang SY [12] & 2017 & $\begin{array}{l}\text { Tribulus terrestris extract was prepared } \\
\text { with } 30 \% \text { ethanol as solvent. The } 1 \% \mathrm{TF} \\
\text { extract with or without } 0.1 \%\end{array}$ & i.p & all days & 24 days \\
\hline Borran M [13] & 2017 & $\begin{array}{c}3 \text { doses of Tribulus terrestris }(100,200 \\
\text { and } 400 \mathrm{mg} / \mathrm{kg})\end{array}$ & Gavage/i.p & all days & 5 days \\
\hline Kumari M [5] & 2015 & 100 or $200 \mathrm{mg} / \mathrm{kg}$ & Gavage & all days & 28 days \\
\hline Raoofi A & 2015 & $100 \mathrm{mg}, 300 \mathrm{mg} / \mathrm{kg}$ or $500 \mathrm{mg} / \mathrm{kg}$ & i.p & all days & 5 days \\
\hline Nishchal BS & 2014 & 100 or $200 \mathrm{mg} / \mathrm{kg}$ & Gavage & all days & 10 days \\
\hline Wei S [6] & 2014 & 25 or $50 \mathrm{mg} / \mathrm{kg}$ com $100 \mu \mathrm{l}$ of saline & i.p & $3 \times$ per week & 4 weeks \\
\hline Heidari MR [14] & 2007 & $50,100,200,400$ or $800 \mathrm{mg} / \mathrm{kg}$ & i.p & NR & \\
\hline Jagadeesan G & 2006 & $6 \mathrm{mg} / \mathrm{kg}$ & Gavage & all days & 7 days \\
\hline Jagadeesan G & 2005 & NR & Gavage & all days & 15 days \\
\hline Kumar [11] & 2006 & $800 \mathrm{mg} / \mathrm{kg}$ & Gavage & all days & 7 days \\
\hline Rathore HS [7] & 2000 & $\begin{array}{l}\text { Tribulus associated others substances } \\
\qquad(12.50 \mathrm{mg} / \mathrm{kg})\end{array}$ & Gavage & all days & 100 or 160 days \\
\hline
\end{tabular}

NR: Not reported by the author; i.p: Intraperitoneal 


\section{Conclusion}

The protection in male reproductive system was the main effects identified in this review, besides this, the increase in antioxidant agents and the anti-inflammatory effect induced by Terrestrial Tribulus supplementation also proved like to be as important effects. These results show that Tribulus Terrestris seems to be an effective supplement for recovery and protection of subjects after intense physical exercise. However, further studies are needed to determine the mechanisms that increase recovery and protection after high intensity physical training.

\section{References}

1. Rogerson S, Riches CJ, Jennings C, Weatherby RP, Meir RA, et al. (2007) The effect of five weeks of Tribulus terrestres supplementation on muscle strength and body composition during preseason training in elite rugby league players. J Strength Cond Res 21(2): 348-353.

2. Amin A, Lotfy M, Shafiullah M, Adeghate E (2006) The protective effect of Tribulus terrestres in diabetes. Ann NY Acad Sci 1048: 391-401.

3. Kianbakht S, Jahaniani F (2003) Evaluation of antibacterial activity of Tribulus terrestres L. growing in Iran. Iran J Pharmacol Ther 2: 22-24.

4. Kumari M, Singh P (2018) Tribulus terrestris improves metronidazoleinduced impaired fertility in the male mice. Afr Heal Sci 18(3): 645-652.

5. Kumari M, Singh P (2015) Tribulus terrestris ameliorates metronidazoleinduced spermatogenic inhibition and testicular oxidative stress in the laboratory mouse. Indian J Pharmacol 47(3): 304-310.

6. Wei S, Fukuhara H, Chen G, Kawada C, Kurabayashi A (2014) Terrestrosin D, a steroidal saponin from Tribulus terrestris L., inhibits growth and angiogenesis of human prostate cancer in vitro and in vivo. Pathobiology 81(3): 123-132.

7. Rathore H (2000) Prevention of toxic effects of mercuric chloride on Some male accessory organs in mice with a Multiherbal drug "Speman." Anc Sci Life 20(1-2): 6-10.
8. Pavin NF, Izaguirry AP, Soares MB, Spiazzi CC, Mendez ASL (2018) Tribulus terrestris protects against male reproductive damage induced by cyclophosphamide in mice. Oxid Med Cell Longev doi: $10.1155 / 2018 / 5758191$.

9. Qureshi A, Naughton DP, Petroczi A (2014) A systematic review on the herbal extract Tribulus terrestris and the roots of its putative aphrodisiac and performance enhancing effect. J Diet Suppl 11(1): 64-79.

10. Alzahrani S, Ezzat W, Elshaer RE, Abd El-Lateef AS, Mohammad HMF (2018) Standarized Tribulus terrestris extract protects against rotenone-induced oxidative damage and nigral dopamine neuronal loss in mice. J Physiol Pharmacol 69(6).

11. Kumar M, Soni A, Shukla S KA (2006) Chemopreventive potential of Tribulus terrestris against 7,12- dimethylbenz (a) anthracene induced skin papillomagenesis in mice. Asian Pac J Cancer Prev 7(2): 289-294.

12. Kang SY, Jung HW, Nam JH, Kim WK, Kang JS, et al. (2017) Effects of the fruit extract of Tribulus terrestris on skin inflammation in mice with oxazolone-induced atopic dermatitis through regulation of calcium channels, Orai-1 and TRPV3, and mast cell activation. Evid Based Complement Altern Med doi: 10.1155/2017/8312946.

13. Borran M, Minaiyan M, Zolfaghari B, Mahzouni P (2017) Protective effect of Tribulus terrestris fruit extract on cerulein-induced acute pancreatitis in mice. Avicenna J Phytomed 7(3): 250-260.

14. Heidari MR, Mehrabani M, Pardakhty A, Khazaeli P, Zahedi MJ (2007) The analgesic effect of Tribulus terrestris extract and comparison of gastric ulcerogenicity of the extract with indomethacine in animal experiments. Ann N Y Acad Sci 1095: 418-427.

15. Pingitore A, Lima GPP, Mastorci F, Quinones A, Iervasi G, et al. (2015) Exercise and oxidative stress: Potential effects of antioxidant dietary strategies in sports. Nutrition 31(7-8): 916-922.

16. Huang WC, Wei CC, Huang CC, Chen WL, Huang HY (2019) The beneficial effects of Lactobacillus plantarum PS128 on high-intensity, exerciseinduced oxidative stress, inflammation, and performance in triathletes. Nutrients 11(2): 1-13. 